\title{
Somatotypes of Patients with Prostate Adenoma
}

\author{
Nikolay Yu Klimov ${ }^{1 *}$, AV Andreychikov ${ }^{2}$ and Yuri Yu Vinnik ${ }^{3}$ \\ ${ }^{1}$ Krasnoyarsk Regional Clinical Oncology Clinic, Kryzhanovsky, Russia \\ ${ }^{2}$ Department of Urology, Andrology and Sexology, Krasnoyarsk State Medical University, Russia \\ ${ }^{3}$ Department of Urology, Andrology and Sexology, Krasnoyarsk State Medical University, Russia
}

Received: 㭗 August 15, 2018; Published: 海 August 24, 2018

*Corresponding author: Nikolay Yu Klimov, doctor, KGBU “Krasnoyarsk Regional Clinical Oncology Clinic named after A.I.

Kryzhanovsky, Russia

\section{Introduction}

\section{Urgency}

One of the most common diseases in men in the second period of adulthood, in elderly and old ages is "Benign prostatic hyperplasia (BPH)." Moreover, if at the age of about 40-49 years, it occurs in $11.3 \%$ of men, after 80 years it is found in $95.5 \%$ [7]. The etiology of prostate adenoma (BPH) exists in the form of hypotheses and it's in many respects controversial.

\section{Objective of the Research}

To establish the most common somatotype of patients with prostatic adenoma (PA) according to the index of Tanner and ReesEysenck body index.

\section{Tasks}

a) To carry out anthropometry;

b) To compare the incidence of somatotypes identified by Tanner and Rees-Eysenck indices in the group of patients with PA and healthy men of the same age.

\section{Materials and Methods}

We examined 150 patients with morphologically confirmed diagnosis who were operated in the urology departments of Krasnoyarsk hospitals. The patients' age was 61-74 years (mean age $67,7 \pm 1,3$ ). Standard anthropometry was made to all of them in 27 parameters [1-3] with the calculation of osteometric indices of Rees-Eysenck [3-4] and Tanner according to the known formulas [1-2]. Anthropometric data taken from the healthy men of the same age were used as a comparison group [5,6]. Statistical data management was made using the Student's test and $\chi 2$. Differences were considered significant at $\mathrm{p}<0.05$.

\section{Results}

Determination of patient somatotype by Rees-Eysenck index showed that men of pyknic somatotype made up $47,4 \%$ (men of the population - 78,6\%; $\mathrm{P}<0,05)$, normosthenic type $-40,6 \%(13,9 \%$;
$\mathrm{P}<0,05)$, asthenic type $-12 \%(7,5 \% ; \mathrm{P}<0,05)$. When comparing the frequency of somatotypes among patients with PA and men of the population there is a significant difference. Patients with $\mathrm{BPH}$ are presented in the majority by pyknic and normosthenic types, while among men of the population the pyknic somatotype considerably prevails. Data of these comparisons are shown on (Figure 1). By distributing the patients into the somatotypes by index of Tanner - the index of sexual dimorphism - it was found out that gynaecomorphic males amount $65.6 \%$, mesomorphic ones - 31.8\% and andromorphic group made up 2.6\%. Compared with the population norms - a striking contrast. Among the patients gynaecomorphic males prevail and andromorphic males are virtually absent (Figure 2).

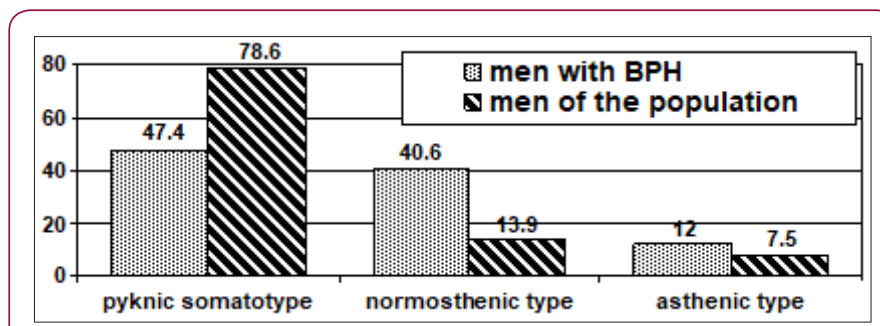

Figure 1: Comparison of the incidence of somatotypes by Rees-Eysenck index among patients with $\mathrm{BPH}$ and male population ( $\%$ of the total number).

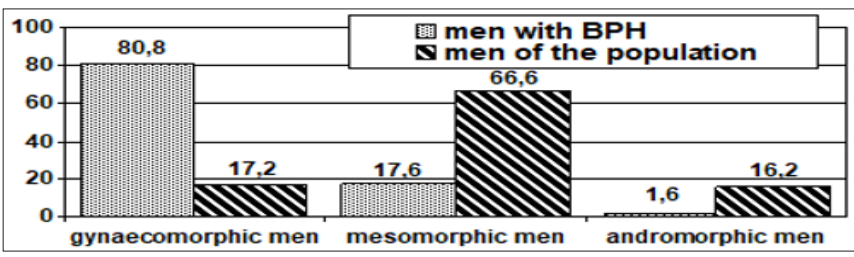

Figure 2: Comparison of the incidence of somatotypes by Tanner index among patients with $\mathrm{BPH}$ and male population ( $\%$ of the total number). 
According to the foreign literature patients with PC, in comparison with male population are obese Fontana S.L and Moorthy K. et al. In our opinion, in recent times a wide spread attempt to explain that carcinogenesis is caused by food conditions in respect of prostate cancer is untenable because while comparing body mass index (BMI) of patients with prostate cancer we obtained the following results: patients with $\mathrm{PC}$ have $\mathrm{BMI}=26,51 \pm 0,62$. When compared with the population data $(\mathrm{BMI}=25,6 \pm 0,23$; $\mathrm{P}>$ 0.05 ) there are no differences! Conclusion: patients with pathology of the prostate and men population are equally overweight.

\section{Conclusion}

a) Among patients with prostate cancer gynaecomorphic and mesomorphic males are found predominantly but gynaecomorphic somatotype is the most frequently occurring. Mesomorphic type dominates among male population. Consequently, estrogens / androgens ratio is of direct relevance to the etiology of prostate cancer.

b) According to our findings: the more developed male characteristics (masculinity), the less prostate cancer probability.

c) According to the body mass index, patients with PC do not differ from the male population, and therefore, excess food and obesity have no relation to prostate cancer.

\section{References}

1. Nikolaev VG, Nikolaeva NN, Sindeeva LV, Nikolaeva LV (2007) Antropologicheskoe obsledovanie v klinicheskoy praktike

ISSN: 2574-1241

DOI: $10.26717 / B J S T R .2018 .08 .001638$

Nikolay Yu Klimov. Biomed J Sci \& Tech Res

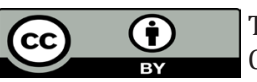

This work is licensed under Creative Commons Attribution 4.0 License

Submission Link: https://biomedres.us/submit-manuscript.php

[Anthropological examination in clinical practice]. Krasnoyarsk, LLC "Verso" p. 173.

2. Lukyanova IE, Ovcharenko VA (2008) Antropologiya [Anthropology]. Moscow, INFA publ, pp. 240.

3. Nikolaev VG, Sharaykina EP, Sindeeva LV, Efremova VP, Sapozhnikov VA (2005) Metody otsenki individual'no-tipologicheskikh osobennostey fizicheskogo razvitiya cheloveka [Evaluation methods of individual and typological features of human physical development]. Kras GMA, pp 111.

4. Nikolaev VG, Sindeeva LV (2010) Opyt izucheniya formirovaniya morfofunktsional'nogo statusa naseleniya Vostochnoy Sibiri [The experience of studying the formation of the morphofunctional status of the population in Eastern Siberia]. Saratov Journal of Medical Sciences 6(2): 238-241.

5. Sindeeva LV (2001) Harakteristika parametrov fizicheskogo razvitiya muzhskogo naseleniya starshih vozrastnyih grupp [Characteristics of physical development parameters of the male population in older age groups]. Synopsis of the thesis, Krasnoyarsk, p. 28.

6. Tanner D (1968) Rost i konstitutsiya cheloveka [Growth and constitution of the person]: trans. from English. / Harrison D, Uayner D, Tanner D, Barnikot N, Human Biology, Moscow, pp. 247-326.

7. Lopatkin AN (2009) Urologiya: natsionalnoe rukovodstvo [Urology: national leadership]. Moscow, GEOTAR Medif, p. 1024.

8. Huggins C, Stevens RE, Hodges CV (1941) Studies on prostatic cancer II. The effect of castration on advanced carcinoma of prostate gland. Arch Surg 43(2): 209-223.

$\begin{array}{ll}\text { BIOMEDICAL } & \text { Assets of Publishing with us } \\ \text { RESEARCHES } & \text { Global archiving of articles } \\ & \text { - Immediate, unrestricted online access } \\ & \text { - Rigorous Peer Review Process } \\ \end{array}$

